\title{
Nigeria's Quest For A Permanent Seat At The United Nations Security Council: An Appraisal.
}

\author{
Dr. Simon Chukasi Ononihu. Prof. Mike. Chidebe. Oddih. \\ International Relations Department,Madonna University Nigeria, Okija Campus. \\ Political Science Department Nnamdi Azikiwe University, Awka.
}

\begin{abstract}
Evidence abounds of Nigeria's quest for a permanent seat in the United Nations Security Council (UNSC). This study examined critically, Nigeria's persisting interest as variously expressed by her principal officers, evaluating its rationality vis-à-vis the objective realities of international politics, the design of the United Nations Security Council and the demands of prudent, appropriate sequencing of national priorities. It relied on documentary and secondary instruments of data generation, logical interpretation and analyses of relevant data. Political Realism is adopted as theoretical framework. The study observed that the veto in particular and permanent membership of the UNSC are not distributed based on ethics, sympathy, fairness, equity or even democratisation but capabilities in terms of national power in all its ramifications. Further, Nigeria is far from being a global 'big power' able to resist coercion and to effectively coerce others, hence there abound urgent necessary domestic imperatives which appropriate sequencing of priorities demand that they should prudently precede the lingering quest. Among the recommendations are profound domestic reforms which would put Nigeria on the road to de-facto big power status, a necessary first step towards realising her persistent ambition. For now, Nigeria should limit herself to non-veto wielding permanent representation of the Africa region.
\end{abstract}

Keywords: Appropriate Sequencing of Priorities, Permanent Membership Status, Political Realism, Quest and Veto-Power

\section{INTRODUCTION}

It was Aluko (1981:265) who articulated Nigeria's national interests as consisting of six important elements, in a descending order of priority as follows; Self preservation of the country, the defense of her independence, the promotion of the economic and social wellbeing of her people, the preservation of their ways of life, especially their democratic values, the enhancement of the country's rating globally and the promotion of world peace. However, over time, Nigeria seems to have added such other aspirations as - (a) The quest to occupy a permanent seat in a reformed and enlarged United Nations Security Council and (b) Inclusion among the twenty largest economies globally, by the year 2020, to her national interests.

Nigeria has therefore joined other countries of the Southern hemisphere in demanding for a reform of the United Nations Security Council (UNSC), in such a manner as to ensure fair representation of all the regions, equity and democratisation of the world body.

The Security Council has enormous powers and responsibilities for the maintenance and preservation of World peace and security as provided in chapters six and seven of the United Nations (UN) Charter. These responsibilities cover preventive, coercive and punitive measures. It is however, provided in article 27 of the Charter that decisions of the Security Council shall be made by the affirmative vote of nine members out of a total of fifteen, inclusive of the concurring votes of all the five permanent members. This is what arms the big five, USA, USSR now the Russian Federation, China, Great Britain and France with the Veto- power.

The founding fathers of the UN recognised that the most powerful and important members should possess special status and responsibilities as a matter of objective reality and so designed the Security Council, institutionalising the requirement of consensus or unanimity among the Great powers, as the basis for ensuring lasting peace in the globe. In this connection, Claude (1971:157) observed that “...the insertion of the veto rule...is an acknowledgement that the outvoting of a great power in a matter of substantial importance is neither a realistic nor responsible way of dealing with the matter". It institutionalises the requirement of consensus among the Great Powers for Security Council action. The device derived from the experiences of the past particularly, the Concert of Europe and the imperatives or realities of International Politics.This paper would critically examine and evaluate the rationality and implications of Nigeria's quest for veto wielding permanent membership vis-à-vis the demands or imperatives of International Politics, described by Morgenthau (1978) as the struggle for power. 


\section{CONCEPTS ELUCIDATION \\ The United Nations Security Council (UNSC)}

It is one of the principal organs of the United Nations, established under article 7 of the Charter. The Security Council consists of fifteen members; (it was eleven before 1965). Ten of the members (formerly six), are non-permanent members, while five are designated as permanent members. These permanent members also referred to as the big five are, The Republic of China, The United Kingdom, The Union of Soviet Socialist Republics (USSR), now The Russian Federation, France and The United States of America (USA). The other ten non-permanent members are by virtue of article 23 of the UN Charter, elected by the General Assembly for a staggered two year term. There is also the provision that no such elected member shall be eligible for immediate re-election.

In electing the non-permanent members, the General Assembly is, as provided in the Charter to give due regard to the contribution of the members to the maintenance of international peace and security, other purposes of the organisation and equitable geographical distribution.The Security Council has primary responsibility for the maintenance of international peace and security as specified in article 24 of the UN Charter. Article 34 of the Charter further gives the Council, the responsibility to investigate any dispute or any situation likely to lead to a breach of international peace and security. All members are obliged to obey the decisions of the Security Council in accordance with the Charter. The Council has two types of matters that concern her, namely procedural and substantive matters. By the provisions of article 27 of the Charter, decisions of The Council on substantive matters require the affirmative vote of nine members, inclusive of the concurring votes of all the five permanent members. This is what leads to the concept of 'Veto- Power', as a negative vote of any of the permanent members on a substantive matter, amounts to a veto of the issue. This now leads to the next concept for clarification.

\section{THE VETO POWER}

It is a mechanism built into the Charter by the founding fathers, to ensure the unanimity of the Super powers. In due recognition of objective reality, the founding fathers had designed The Security Council, to operate on the principle of unanimity of the Great Powers. This was based on the understanding that the combined powers of the Super Powers will be so overwhelming that enforcement of decisions or sanctions on any issue on which they all concur, will be successful. Indeed, the mere concurrence of the Super Powers on any matter serves as adequate deterrent to any would be aggressor or dissident.

It was also intended to be a veritable safeguard or guarantee of the rights of a powerful minority and mitigation of the evils of international majoritarianism. The veto provides a possible escape opportunity or safety valve from the catastrophe that would follow any attempt to enforce sanctions or decisions against the determined opposition of any of the Super Powers. This is why Claude (1971:156), described the veto as "a deliberately contrived circuit breaker in the decision making process of the Security Council”.

The veto power can also be described as a device for the acknowledgement of the inequality of states. This is why it is not based on equitable representation, democratization, or even fairness. It grants special status to the most powerful states by allotting to them, heavier or bigger votes. In the design of the UNSC, the founding fathers even ensured protection of the veto power, by providing in Article 108, that any amendment to the Charter requires the concurring votes of all the permanent members. It is also note worthy that the coming into effect of the Charter required the affirmative ratification of all the permanent members.

\section{THEORETICAL EXPOSITION}

This paper adapts the theory of political realism as a framework of analysis. The Philosophers associated with the theory include: Thucydides, Machiavelli, Hobbes, Morgenthau and Aron. They advocate rationalism, prudence and realism in international relations. Their postulations stem from their conceptions of the inherent nature of man, society and politics. Man, to them, is inherently evil, sinful, power-seeking, egocentric, competitive and prone to conflict.

Similarly, Nation-States have goals and interests that are conflicting. Attempts to promote or attain them at the expense of others make conflicts and war inevitable. Hence, Nation-States prepare for war by continually updating and upgrading their capabilities in terms of power. Power here refers not only to military power but also to all the elements of national power which encapsulate economic, technological, political, demographic, geographic and other elements. For the purposes of expatiation, one of the best categorizations of these elements was done by Macridis (1972). He identified key elements, classified under three main headings as follows:

1. The relatively permanent material elements - geography, energy and power, natural resources, food production capability.

2. The less permanent material elements - industrial establishments, military capability and technological level. 
3. The human elements - quantitatively in terms of population size or demography and qualitatively as it concerns quality of leadership, the role of ideology and information.

This was why Nweke (1985:1), asserted that “...the foreign policy of any Nation is a function of the strength, cohesion and resilience of its economy, society and polity".

The essence of politics is universally acknowledged as 'interest', defined in terms of power. In other words, ability to protect, project and promote national interests is contingent on capabilities, calculated in terms of national power. Obviously then, power calculations or capabilities remain a crucial determinant of the extent a country can be reckoned with or otherwise in the global arena. In this instance of the UN Security Council's permanent membership, the 'Veto' is not distributed based on ethics, sympathy, friendship, benevolence, fairness, equitable representation or even democratisation. Evidently, it is based on power calculations or objective realism. Hence, Claude (1971:153) wrote that “...the veto is a weighting device, an acknowledgement of the inequality of states and a means of giving effect to the principle that the most powerful and important states should have special status in international organisations". There is no gain saying that any Nation-State aspiring for Veto power should at least, possess the capabilities to exercise it. Is it not thus rationally objective that States should seek first the capabilities, so that, every other thing shall be added unto them? The example of mainland China (1949 -1973) suffices as illustration of this objective rationality.

The big question from this perspective of political realism remains, is Nigeria capable of exercising the Veto power, if by any chance it is granted to her? Has she become a de-facto big power, able to resist coercion and to effectively coerce others? Herein lays the futility of insistence on that level of reform of the UN Security Council, as reported in Uhomoibhi (2008:232). As admonished by Thucydides, we should be on guard against naïve dreaming, realising that it is utopian to ignore the realities of power in international politics.

\section{EVIDENCE OF NIGERIA'S PERSISTING QUEST}

Nigeria has evidently utilized opportunities available to her, not only to express but literally, to canvas its aspiration for a permanent seat in an enlarged and reformed Security Council of the United Nations. Since her political independence in 1960 and subsequent admission as the $99^{\text {th }}$ member of the UN, Nigeria has had to represent Africa as a non-permanent member of the United Nations for unprecedented five times; in 1966-67, 1978-'79, 1994-'95, 2011-'12 and 2014-'15.

None the less, Nigeria has not disguised its interest, or preferably, ambition to be one of the Veto wielding members of the United Nations Security Council (UNSC)-the world body's most powerful institution, whenever the reform of the Organ is achieved. As recorded by Uhomoibhi (2008:233), the first shot was fired “ in 1991 when the country's Head of State, General Ibrahim Babangida, addressed the UN General Assembly... and was reaffirmed in June 2000 by the Minister of State for foreign affairs, Dubem Onyia, in a meeting with a delegation representing Kofi Annan, the Ghanaian born UN Secretary-General at the time".

Unrelenting, President Goodluck Jonathan, while playing host to the then British Prime-Minister, David Cameron, precisely on $19^{\text {th }}$ July 2011 in Lagos, as reported by Alabi, Wole \& Chukwuma (2011) canvassed for British support to Nigeria's quest for a permanent seat in the UN Security Council. President Jonathan had argued that Nigeria shoulders about $75 \%$ of the security challenges in the West-Africa sub region, besides being a major contributor to peace keeping efforts globally. He was quoted as having told his guest, "let me use this opportunity to request that the Security Council be liberalized and democratized. Africa needs to be represented. Nigeria having paid her dues in terms of contributions to world peace remains the best African country in that regard".

Sustaining the lingering ambition, the current Vice-President Prof. Osinbajo, while delivering a key note address at the launching of the Global Commission Report at the International Conference Centre Abuja, stated that Nigeria deserves a permanent membership position in the Security Council of the UN, in view of the country's contributions to international peace-keeping, size of its economy and population. As reported by Usman (2015) Prof Osinbajo had argued that "since Africa is the only continent without a permanent seat in the UN Security Council, Nigeria has the strongest profile to represent Africa and so, balance the membership composition of the Council".

Confirming Nigeria's aspiration, President Muhammadu Buhari while at the $71^{\text {st }}$ Session of the United Nations General Assembly (UNGA '71), made a case for Nigeria to be the African permanent representative on the UNSC. He was quoted by Adetutu (2016:6) as having said, "Africa should be adequately represented on the United Nations Security Council in the permanent member category. In this regard, Nigeria stands ready to serve Africa and the world in a reformed Security Council to advance international peace and security". It is observed that President Buhari adroitly avoided specifying the status of permanent membership sought by Nigeria.

It is pertinent here to note that the long drawn debate on the reform, enlargement and democratization of the UNSC had produced three clear options or perspectives. As recorded by Uhomoibhi (2008:232), these perspectives are: 
I. two categories of permanent and non-permanent memberships, plus a third which would be permanent but non- Veto wielding;

II. the two existing categories, plus a third which would be semi permanent and rotational between two or more countries from the same region; and

III. an enlargement of the Council which maintains the two levels of representation, but increases its membership at both levels to reflect equitable geographical representation and demographic distribution.

The discernible evidence is that Nigeria routes for the third category of the proposal. This can be deduced from the report giving by Uhomoibhi (2008:233) that;

The UN high level panel set up by Kofi Annan to review security threats, submitted its report in December 2004 and proposed two permanent seats for Africa in a Security Council that would be expanded from fifteen to twenty-four members. However, the failure to secure majority African support for dropping the insistence on the Veto - a position Nigeria and South-Africa both supported scuttled any chance of reforming the Security Council in the reform process of 2005.

Deductively therefore, Nigeria's strategic ambition has been for a Veto-wielding permanent member status. Nigeria has consistently proposed that such criteria as contribution to the maintenance of global peace and security particularly at the regional and sub-regional levels, demographic distribution or strength of nations, and the economic potentials of states, should be given prominence in the proposed reform process. This was probably why President Goodluck Jonathan in a spirited effort to justify his request while persuading his Guest, Prime-Minister David Cameron, asserted that Nigeria shoulders about $75 \%$ of the security challenges in the West- Africa sub region.

\section{Appraisal}

In evaluating Nigeria's quest, one may be tempted to justify her persisting ambition, given that as Aluko (1981:265) articulated, one of Nigeria's national interests is the promotion of the country's global rating, status or prestige. This is consistent with the "four main purposes of foreign policy, common to all contemporary states (1) security; (2) autonomy; (3) welfare, broadly conceived; and (4) status or prestige" as postulated by (Holsti 1995:84). Given Nigeria's acknowledged contributions to peace-keeping efforts both regionally and globally, her demographic strength, economic potentials and strategic position in the Africa region and West Africa sub-region, the aspiration for a permanent seat in a reformed and enlarged UNSC, appear justified. After all, the essence of foreign policy as universally acknowledged is the promotion of national interests. Obviously, Nigeria's attainment of permanent membership status on the UNSC will be a stupendous boost to her global diplomatic significance. Additionally, Nigeria's performances as a nonpermanent representative of the Africa region amply demonstrates that she can boldly and unequivocally, speak on matters of concern to the continent.

However, considering the dictates of the theory of political realism and the demands or logic of appropriate sequencing of priorities, the rationality in dissipating energy and scarce resources in the perpetual pursuit of such remote strategic goal which realistically is elusive or even when realized, at best pyrrhic, particularly in respect of the Veto-wielding permanent membership status which Nigeria is reportedly routing for, becomes not only doubtful but questionable, if not outright misplacement of priority.

If, as revealed by Uhomoibhi (2008), Nigeria's and South-Africa's refusal to drop the insistence on Vetowielding permanent membership status, scuttled the 2005 UN Reform process, initiated by Kofi Annan, one could rightly state that the country is ostensibly oblivious of the essence of the Veto, the design of the UNSC (borrowing from Onu 2000:16), and the long standing principle of "unanimity of the Super Powers". In other words it is crass naivety or mildly put, outright exhibition of ignorance of the very basis of the Veto wielded by the Super Powers and the design of the UN Security Council.

The 'Veto' in the Security Council dates back to the $19^{\text {th }}$ Century Concert of Europe- the Concert of Great Powers. This was carried through the Council of the League to the Security Council of the UN. The essence being that enforcement or implementation of punitive mandatory sanctions would pose minimal or no problem, once the Super Powers are agreed but would obviously be very difficult if not deleterious to global peace and security, where an attempt is made to enforce any substantive issue against the determined opposition of any of the Super powers.

The pertinent questions that arise are, what will Nigeria do with a Veto- power, if by any chance it is offered to her? Of what use will it be to the country given its capabilities in terms of the elements of national power? If as observed by Azikiwe (1968) "the element of greatness stems from within" and as noted by Nweke (1985) "the foreign policy success of any country is a function of the strength, cohesion and resilience of its economy, polity and society, is it not rationalism and due observance of appropriate sequencing of priorities?, to heed the admonishment of Olusanya \& Akindele (1986:11), who emphasized that "In the final analysis, preparation for as well as the capacity to play an active and credible role in world affairs begins from the 
domestic front and depends on how well mobilized the domestic base is". In the same vein, Oyebode (2010:14) observed that,

If you look at the country and the prostrate economy, you look at the unspeakable mismanagement of resources, the unbelievable corruption; Nigeria's profile internationally is nowhere. ...by the time we get to that level when we have taken care of power problem, unemployment, health-care, when our president would not have to go to a foreign hospital for treatment,... by the time we have taken care of all these domestic challenges, then Nigeria can stake a claim to making waves internationally. Right now we are just being grudgingly tolerated, because we have not demonstrated to the outside world the capability to transcend our difficulties, to turn our difficulties to opportunities.

Is it not ridiculous that President Jonathan while requesting Prime-Minister Cameron, for British support of Nigeria's quest, agreed with him in the same meeting "that current electricity supply in Nigeria is equivalent to that of the city of Bradford, UK"? A country that was soliciting for a Veto-wielding permanent status in the UNSC had a power generating capacity of an all time best of 5000Mw. As reported by Adeola (2017:5) "The power sector, according to the Nigerian Electricity Supply Industry (NESI) operational report for January 4, 2017, hit a peak generation of 4,959 megawatts, but dropped to 2,664 megawatts on January 22, 2017". Indeed, Nigeria's Power generating capability has for the past seventeen years, been oscillating between 1,500 and 5000Mw. Comparatively, South-Africa and Egypt here in Africa, as of 2009, generated 36,000 and 23,000Mw respectively. It may be pertinent to note, as reported by Okon (2009) that:

United States of America with a population of 307 million has a generating capacity of about 995,000 Mw. China with a population of 1.3 billion generates approximately 713,000 Mw and the United Kingdom with a population of 62 million generates close to 74,000Mw. Closer home to Nigeria on the African continent, SouthAfrica with a population of 49 million has a generating capacity of 36,000Mw and Egypt with a population of 77 million generates roughly $23,000 \mathrm{Mw}$ of electricity. Nigeria with a population of approximately 155 million (UN) estimates has a current generating capacity of $4,500 \mathrm{Mw}$ and will need ten times this capacity to par with Egypt in terms of capacity per population.A more recent ranking of countries by electricity production per year based on multiple sources with date of information (retrieved from the Internet), shows that Nigeria's position has not improved. Nigeria is ranked a distant $67^{\text {th }}$, while South Africa and Egypt are ranked $18^{\text {th }}$ and $26^{\text {th }}$ respectively. The information is shown in the table below.

Table 1: List of Countries by Electricity Generation Per Year, with Date of Information.

\begin{tabular}{|l|l|l|l|l|}
\hline S/N & COUNTRIES & $\begin{array}{l}\text { ELECTRICITY } \\
\text { PRODUCTION } \\
(\mathrm{GWh})\end{array}$ & $\begin{array}{l}\text { YEAR OF } \\
\text { INFORMATION }\end{array}$ & RANKING \\
\hline 1 & China & $6,142,490$ & 2016 & 1 \\
\hline 2 & USA & $4,297,300$ & 2014 & 2 \\
\hline 3 & India & $1,208,400$ & 2014 & 3 \\
\hline 4 & Russia & $1,064,100$ & 2014 & 4 \\
\hline 5 & Japan & $1,061,200$ & 2014 & 5 \\
\hline 6 & Canada & 615,400 & 2014 & 6 \\
\hline 7 & Germany & 614,000 & 2014 & 7 \\
\hline 8 & Brazil & 528,600 & 2014 & 8 \\
\hline 9 & France & 555,700 & 2014 & 9 \\
\hline 10 & South Korea & 517,800 & 2014 & 10 \\
\hline 11 & U K & 356,800 & 2013 & 11 \\
\hline 12 & South Africa & 256,100 & 2013 & 18 \\
\hline 13 & Egypt & 148,500 & 2013 & 26 \\
\hline 14 & Algeria & 58,300 & 2013 & 48 \\
\hline 15 & Libya & 25,957 & 2011 & 66 \\
\hline 16 & Nigeria & 25,695 & 2011 & 67 \\
\hline 17 & Morocco & 23,652 & 2011 & 69 \\
\hline
\end{tabular}

Source: https://en.wikipedia.org/wiki/list_of_countries_by_electricity_production. Accessed on 2nd march 2017.

Besides the dismal Electric Power infrastructure, other debilitating domestic factors which rationality demands should be first combatively addressed and considerably assuaged, include endemic corruption, abject poverty, massive unemployment, abysmal human development indices and lack of good governance.

\section{Endemic Corruption}


Corruption in Nigeria has remained a major setback to progress. It has greatly smeared its global image and perception. The immediate past British Prime Minister David Cameron, had described Nigeria alongside Afghanistan as "fantastically corrupt". It is not only pervasive but has eaten deep into Nigeria's bone marrow as it were. The magnitude is so alarming that Transparency International has consistently ranked Nigeria as one of the most corrupt countries in the world. The organization's 2014 Corruption Perception Index, sourced from the Internet, ranked Nigeria " 136 out of 176 countries with a score of 27 out of 100 ". The same source revealed that 'Global Financial Integrity', estimates that "more than US\$157billion left Nigeria corruptly in the past decade". In discussing the problem with Nigeria, Achebe (1998) had noted that "corruption in Nigeria has passed the alarming and entered the fatal stage and Nigeria will die if we keep pretending that she is only slightly indisposed". Virtually every day, the News Media is awash with stories of mind burgling, heinous embezzlement of the State funds. This is quite pervasive as no sector is exempt. If it is not Politicians, it is Service Chiefs, Managing Directors of Public Institutions, Banks and even Judges at all levels. This year alone, there have been reports of US\$9.8million and $£ 174,000$ sterling cash, recovered from the home of a former Managing Director of the Nigerian National Petroleum Corporation (NNPC). Additionally, a whooping sum of US\$153.7million recovered by the Country's Economic and Financial Crimes Commission and traced to a former Minister of Petroleum. Though the current Federal Government appears serious with efforts to tackle the monster, there is need to strengthen the anti-corruption bodies, sustain and improve the anti-corruption measures to ensure that the entire Nigerian body politic is profoundly permeated.

\section{Abject Poverty}

Another debilitating element which is closely connected with corruption is abject poverty. Nigeria's National Bureau of Statistics estimates that " $60.9 \%$ of Nigerians in 2010 were living in absolute poverty-this figure had risen from $54.7 \%$ in 2004". It further demonstrates the rising poverty trend in Nigeria with the following statistics;

Table 2: Nigeria's Rising Poverty Rate, (Feb. 2012 Report)

\begin{tabular}{|l|l|l|}
\hline S/N & RATE OF POVERTY & YEAR \\
\hline 1 & 17.1 million people & 1980 \\
\hline 2 & 34.7 million “ & 1985 \\
\hline 3 & 39.2 million “ & 1992 \\
\hline 4 & 67.1 million “ & 1996 \\
\hline 5 & 68.7 million " & 2004 \\
\hline 6 & 112.47 million “ & 2010 \\
\hline
\end{tabular}

Source: Nigeria's National Bureau of Statistics, retrieved from www.bbc.com/news/word-africa17015873 on 3rd March, 2017.

Collaborating the fore stated observations, Sunday Punch (2010:10), wrote that “...as at 1999, less than $50 \%$ of Nigerian's were living below poverty level, but the number has since gone beyond $70 \%$. This was despite the fact that Nigeria's oil which sold for $\$ 10$ in 1999 , rose gradually to an all time high of $\$ 147$ per Barrel". This rising poverty profile contrasts sharply with the Chinese position where poverty level reportedly shrank from $56 \%$ to $12 \%$, in the last 35years.Similarly, the World Bank data ranking countries by "the percentage of their population with an income of less than \$1.90 and \$3.10 United States Dollars per day in 2011 dollars, at purchasing power parity", gave comparative figures for Nigeria, South Africa and others as follows:

Table3. List of countries selected from the data.

\begin{tabular}{|l|l|l|l|l|}
\hline S/N & Country & Year & $\$ 1.90$ & $\$ 3.10$ \\
\hline 1 & Nigeria & 2009 & $53.47 \%$ & $60.5 \%$ \\
\hline 2 & South-Africa & 2011 & $16.56 \%$ & $34.68 \%$ \\
\hline 3 & Morocco & 2007 & $3.12 \%$ & $15.53 \%$ \\
\hline 4 & China & 2013 & $1.9 \%$ & $2.5 \%$ \\
\hline 5 & Russia & 2012 & $0.04 \%$ & $0.48 \%$ \\
\hline
\end{tabular}

Source:https://en.wikipedia.org/wiki/list_of_countries_by_percentage_of_population_livi

The foregoing statistics both from the World Bank and Nigeria's National Bureau of Statistics aptly confirm the pervasiveness of poverty in Nigeria. What is even more disturbing is the worsening situation. The Daily Sun (2017:15), had in its editorial, lamented Nigeria's rising misery index profile. According to the report, "Nigeria's position on the global misery index has risen to a record 49.5\% from 47.7\% in August 2016". Nigeria is now ranked $4^{\text {th }}$ on the global misery index.

Obviously a country whose poverty and misery levels are steadily rising cannot have the strength, cohesion and resilience needed at the domestic level for successful foreign policy. One may have to ask, of what use is it for a 
country to be scheming for veto power wielding permanent seat at the UNSC, when about $70 \%$ of her population live below poverty line and $49.5 \%$ of the citizenry wallow in unmitigated misery. Certainly, Nigeria's global ranking in poverty and misery levels cannot provide the necessary domestic foundation required for the projection of respectable profile considered sine qua non for the realization of her ambitious global strategic goals.

\section{Lack of Visionary Leadership and Good Governance}

Nigeria's unappealing domestic profile could considerably be attributable to lack of good governance and leadership. Unfortunately, the country has had to grapple with the problem of lack of visionary, patriotic and inspiring leadership. Arguably, the very few occasions the country could be said to have had a semblance of good leadership, the tenure was abruptly cut short. Good governance is one attribute that makes tremendous difference in the fortunes and reputation of countries. Achebe (1998:5) had noted that "the trouble with Nigeria is simply and squarely a failure of leadership ...the Nigerian problem is the unwillingness or inability of its leaders to rise to the responsibility, to the challenge of personal example, which is the hallmark of true leadership". Similarly, Buhari (1985:1) noted that " ...no country in the world can command the respect and admiration of the international community without a dedicated and purposeful leadership".

Dwelling on the same issue, Obiozor (2010:26) observed that;

We must accept that all the conflicts and tensions in Nigerian politics are not the figments of some people's imagination. Many of them originate from real issues and require strong and self confident leadership to resolve. De Gaulle did it for France, Mahatma Gandhi for India, Nkrumah for Ghana, Mandela for South Africa, Ataturk for Turkey, Lenin for Russia, Frank Roosevelt for the US, Mao Tse Tung for China, etc. These were heroic leaders of extra-ordinary talents, tenacity and vision with the capacity to mobilize and inspire their entire nations. They all overcame inherently divisive cleavages and other disintegrative forces to establish strong and united countries. Nigeria needs now as in the past, such heroic national leadership.

Leadership therefore remains one of the greatest domestic challenges which Nigeria must necessarily address squarely, before it can earn respect and make waves globally.

In terms of human development indices, Nigeria's record is equally abysmally poor. Infant and maternal mortality rates in Nigeria are about the highest in Africa. Literacy, malnutrition, unemployment levels, average life-span, security of life and properties to mention but a few, are all at abysmal levels. According to a World Bank report retrieved from the internet, Nigeria has "over 3.3million Internally Displaced persons (IDP), which is Africa's largest, ranking behind Syria and Columbia on a global scale". As if that is not enough, the 2016 UN report on Nigeria stated that,

In Nigeria, 37\% of children under five years old were stunted, $18 \%$ wasted, $29 \%$ underweight and overall, only $10 \%$ of children aged 6-23months are fed appropriately based on recommended infant and young children feeding practices....Youth unemployment which is $42 \%$ in 2016 is very high creating poverty, helplessness, despair and easy targets for crime and terrorism. Over 10million children of school age are out of school with no knowledge and skills.

At present, Nigeria's mono economy is in recession. Nigeria is unable to exploit its God given natural resources. Though a key member of the Organization of Petroleum Exporting Countries (OPEC), it is dependent on imported petroleum products. Its refineries are not only obsolete but she is neither able to perform due TurnAround maintenance nor able to build new ones. Indeed Nigeria's Minister of State for Petroleum Resources, Dr. Ibe Kachikwu was quoted by Eboh (2016:5) as warning that " unless urgent steps were taken to immediately revamp the country's refineries, they might become scraps in 2019". It is also proven that Nigeria has large deposits of Bitumen but depends on imports of the product, for its Asphalt needs, as it is unable to harness its own.

In view of the above scenario, one wonders what use the veto-power wielding permanent membership will be for Nigeria, if by any consideration it is even freely offered to her. Given the utterly underdeveloped picture presented by Nigeria, one cannot but agree with Osakwe (2011:4) that "the urgent priorities ---in Nigeria must be to establish security of life and property, restore law and order, rebalance and stabilize macroeconomic management and provide efficient, stable and cost effective infrastructure. ---These priorities must precede grand ambitions for regional and global leadership...".

In a similar vein, Uhomoibhi $(2011: 114)$ noted that:

...no country is ever accepted as a leader on account of her own perceptions. Rather States must struggle to be respected, first by focusing on developing the domestic environment to be economically buoyant and through a political governance regime that is inclusive, fair and transparent. Leadership is not conferred based on self -perception, but on the perception of others in a global system characterized by increasing competition and rivalry.

\section{CONCLUSION}


Certainly, it is foolhardy to pursue the shadow and leave the substance. Unfortunately, beside leadership crisis, wrong prioritization is one of the serious maladies bedeviling the Nigerian state. Given the enormous responsibilities of the UNSC, as provided in chapters six and seven of the UN Charter, the design of the Security Council and the very essence of the Veto, particularly with reference to the time honoured 'unanimity of the Super Powers', it is of no use for inconsequential Powers to dissipate resources and energy aspiring for Veto-wielding membership under any guise - be it democratization or fair representation.

In the circumstance, we cannot but agree with Osakwe (2011:4) where he admonished that "the appropriate sequencing of the key domestic national priorities must surely precede the pursuit of strategic goals for regional and global leadership". Obviously, Nigeria's sorry domestic situation need urgently to be decisively addressed, before such 'wild Goose chase' of farfetched strategic goals. To do otherwise, amounts to "putting the cart before the horse".

Ruminating over our lamentable domestic situation, Hon. Eyibor, one time Chairman Information committee of Nigeria's House of Representatives, was quoted by Effiong (2009:8) as having likened Nigeria to, "a dilapidated building which needs a comprehensive restructuring to make all sectors work. There are crises in all sectors like Agriculture, Health, Transportation, Information, Power ---and even the Niger-Delta, all of which require urgent attention". Similarly, Tinubu (2010) opined that, at 50, the Nigerian House is in a sad state and it constitutes a health hazard to us, if something is not done on time to save the situation. To save Nigeria from imminent collapse --- we have to look at the foundation of the House as no Architect can reconstruct a skyscraper from the roof top.

It is instructive that as early as 1985, the present Head of State, President Buhari had observed that "--no country can conduct a successful foreign policy without first putting its house in order". True it is that Nigeria is great demographically but is that parse, sufficient criteria for her to deserve a permanent seat in the UNSC? Should that even be our immediate concern and appropriate priority?

As observed by Lyman (2010-:14); Chinese power comes not just from the fact that it has a lot of people but it has harnessed the entrepreneurial talents, economic capacity and all other resources of China to make her a major economic and political force globally---

Evidently, Rodney was right when he affirmed that, development is a process of increasing the ability and capacity of a people to exploit the resources of their environment, so as to satisfy their needs at any given time. "A society develops ....as its members increase jointly their capacity for dealing with the environment" (Rodney 2009:2). Nigeria at the moment is neither able to harness, process nor refine its natural resources in sufficient volume to satisfy its domestic needs. It is the only OPEC country still depending on imported petroleum products. Bitumen an essential raw material for tarring of roads so necessary in Nigeria, abound in large commercial quantities in the country but it is imported as the country is unable to exploit her own.

Nigeria is not even a member of the twenty largest economies, the (G-20), not to talk of the G-4 (Brazil, Germany, India and Japan), and it is virtually certain that it will not attain its aspiration to be counted as one by year 2020 (its vision 20-2020). Beyond mere sentiments, Nigeria should avoid self delusion and not hide under fair representation, democratization (which of course is yet to be entrenched in Nigeria) or any such claims to obtain what it cannot exercise. After all, Nigeria has for good five tenures, served in the UNSC on nonpermanent status whereas the evidence is that over $60 \mathrm{UN}$ member states have never had such opportunity since political independence. This is proven confirmation that Security Council membership and in reality the whole design of the UN, were not conceived as a matter of democratization, equity, fair representation or any of the likes but on Power and objective reality. In view of the fore going, realists like Aron were right when they contended that, it is power rather than any morality that determines or motivates foreign policy. We should therefore get our priorities right.

Writing on democratization of the UN, Onu (2000:18) noted that:

... I also think that achieving a peaceful world is one of the principal objectives of the United Nations. Democracy, where pursued to its logical ends may create a kind of order which may even be far from being peaceful if realities are neglected. It is contended that a lasting peace could only be talked about if the world could face the objective realities. In pursuit of democracy, do we chase what is real and right or that which is ideal and utopian?

It does appear that President Muhammadu Buhari and the current Nigerian Government have become weary of the futility of insisting on the 'Veto', as in his speech at the recently concluded $71^{\text {st }}$ session of the United Nations General Assembly (UNGA), he rationally and deliberately avoided mentioning the Veto but only offered Nigeria's willingness to serve on a permanent status. This is more realistic and feasible.

Nigeria should divest itself of the idea of Veto and seek for a reform that would have her as a non-veto wielding permanent representative of the African Region. This is however, contingent on the speedy and drastic restructuring of her domestic domain as well as, quickly purging herself of all opprobrious domestic situations which had in the past given her a pariah status. 


\section{RECOMMENDATIONS}

1. Realism

In view of the fore-going scenario, it is our considered suggestion that Nigeria should steer clear absolutely, of any pretensions to a 'Veto' wielding permanent status. The Nation's focus should be on the first of the three reform proposals, which specifically is -a reformed and enlarged Security Council with a third category of non-Veto wielding permanent members, ensuring equitable and fair representation for all regions. This is certainly more realistic and feasible. Since veto wielding permanent status is based on power calculations, it is futile aspiring for it without acquiring the necessary power profile. Though Article 23 of the Charter requires that due regard be specially paid, to the contribution of members of the United Nations to the maintenance of international peace and security, as well as equitable geographical distribution, it is in respect of the election of the non-permanent members. The Great Powers are more likely to accede to a reform programme proposing increase in the permanent membership without a veto than with veto power. More importantly, veto power not backed by proven power dispositions, is simply pyrrhic and futile. It does appear that the present Nigeria Government has imbibed this suggestion, as President Muhammadu Buhari in his address at the $71^{\text {st }}$ Session of the UNGA, carefully avoided any mention of the status of permanent membership, sought by Nigeria. He only stated that "Africa should be adequately represented ....in the Permanent member category .... Nigeria stands ready to serve Africa and the world in a reformed Security Council, to advance international peace and security".

\section{PROFOUND DOMESTIC REFORMS}

Given the crucial role domestic factors play in the determination of a country's external or global rating, which as a result of the ever increasing globalisation and improved technological factors, have become even more critical, there is need for sweeping profound domestic reforms to shore up Nigeria's rating or estimation globally. A situation where the nation cannot harness its natural resources and continually trudge on a wobbling mono-cultural economy with all its pernicious effects, does not do the image and perception of the country any good. Similarly, being rated as one of the most corrupt, with prevalent unemployment, pervasive poverty and perpetual insecurity, cannot give the country the required respect and reputation to be reckoned with globally. There should therefore be concerted and sustained effort at sweeping domestic reforms. Such inevitable domestic reforms should encompass the following.

\section{(i) Diversification of Nigeria's Economy}

There is urgent need for conscious diversification of the Nigerian economy, away from the sale of crude-oil. The Nation-State ought to have moved to the level of export of fully processed or at least semiprocessed products. It is not only insulting but deleterious to the Nation's image and economy that up to the contemporary period, the country still imports refined premium spirit or petroleum products. It is certainly ridiculous that Nigeria which was a net exporter of refined products in the 1970's, paradoxically is now a net importer of the products, without a fit functional Refinery in the new millennium. Indeed the current Minister of State for Petroleum, Dr. Kachikwu, recently disclosed that Nigeria's Refineries would even be scraps by 2019 . This was one of the reasons Rodney (1972) held that substituting the term developing for under-development in the Third world, is misleading.

Lip service should no longer be paid to the rational imperative of economic diversification. The development of Agriculture, Agro-based industries, the exploitation and processing of Solid minerals like Bitumen should be actively driven by Governments in Nigeria.

\section{(ii) Sustained Anti-Corruption Measures}

It is equally very pertinent that the anti-corruption crusade be sustained, the Anti-Corruption Agencies be strengthened and transparent. Corruption has been a monster and great impediment to efforts at domestic development. Nigeria cannot hope to be taken serious by the international community, when it is 'fantastically' corrupt. In this regard, Adedeji (as quoted in Adebajo 2008:1) observed that "No country that is confronted with a long period of political instability, economic stagnation and regression and is reputed to be one of the most corrupt societies in the world, has a moral basis to lead others. If it tries to, it will be resisted". It is therefore very germane that corruption and misery be drastically reduced to the barest minimum possible.

\section{(iii) Poverty Alleviation}

It is despicable that poverty and misery have been increasing geometrically in Nigeria. Pervasive poverty and misery are not attributes of greatness and cannot provide the resilient and coherent domestic environment necessary for successful foreign policy. There should therefore be a well articulated, transparent and sustained poverty alleviation strategy. A successful fight of the endemic corruption in the country is one 
veritable way of alleviating corruption. Skill acquisition, reduction of unemployment and the liberalisation of credit facilities recommend themselves.

\section{(iv) Sustained Massive Infrastructural Development}

Aggressive, massive infrastructural development is another sine-qua-non or domestic imperative which will shore-up Nigeria's economy, polity, prestige and global rating. Power generation and supply, should be given special attention. A country that boasts of only $5000 \mathrm{Mw}$ or even the recently speculated $7300 \mathrm{Mw}$, is still a rural economy and therefore in no position to contest for either leadership or supremacy with contemporaries in the region who possess generating and consumption capabilities and actualities that far surpass this subsistence level. It is also sad commentary and shameful that Nigeria's Refineries are virtually obsolete. The Iron and Steel project, as well as the Railway projects should all be tackled with the seriousness they deserve.

\section{(V) Good Governance}

Effective and sincere political leadership is the missing link which is required to co- ordinate, inspire and lead the push for a new Nigeria. A leadership that besides being accountable, is visibly responsive, responsible, equitable, nationalistic and so motivating or inspiring. It is such leadership that can change the numerous debilitating factors in Nigeria's domestic environment and earn international respect for the country. These rationally observing, are the very modicum of domestic imperatives which should be priority and should indeed precede the aspiration for global leadership and prestige. They represent the least required to put Nigeria on the road to de-facto big power status, a necessary first step to the attainment of its lofty aspirations.

\section{REFERENCES}

[1] Achebe, C. (1998). The trouble with Nigeria. Enugu: Fourth Dimension Publishing Company.

[2] Adebajo, A. (2008). Hegemony on a shoe string, Nigeria's post cold war foreign policy. In A. Adebajo \& A. R. Mustapha (eds), Gulliver's Troubles, Nigeria's Foreign Policy after the Cold War (pp.1-37). Cape Town: University of KwaZulu-Natal Press.

[3] Adeola, Y. (2017). Power generation crashes by 1, 297Mw in 18 days. New Telegraph, January 23, pp1\&5.

[4] Adetutu, F.K. (2016). Return stolen loots, Buhari tells UK, US. How we are spending recovered cash says President. Daily Sun, September 21, p.6.

[5] Alabi, W; Wole S. \& Chukwuma M. (2011). Nigeria, Britain raises bar on trade ties, new DFID schemes to double electricity by 2015 . The Guardian, July 20, pp.1-2.

[6] Aluko, O. (1981). Essays in Nigerian foreign policy. London: George Allen and Unwin.Azikiwe, N. (1968). Renascent Africa. London: Frank Cass and Co. Ltd.

[7] Buhari, M. (1985). Nigeria's foreign policy. Nigerian Journal of International Affairs 10 (2) pp..17.Claude Jr. I. L. (1971). Swords into ploughshares: the problems and progress of international organization. Random House, Inc. New York.

[8] Dailypost.ng/2016/09/05/Nigeria-one-poorest-countries-world-80m-living-poverty.Daily Sun, February 6, $2017 \mathrm{p}-15$.

[9] Eboh, M. (2016) “ Our refineries will become scraps by 2019, if ... Kachukwu”. The Vanguard, Nov. 18 pp. $1 \& 5$.

[10] Effiong, J. (2009) "Nigeria is like a dilapidated building -Rep". Daily Sun, August 12, p8.Holsti K. J. (1995) International Politics. A framework for Analysis .New Jersey: Prentice Hall

[11] International Inc.

[12] http://en.wikipedia.org/wiki/list_of_countries_by_electricity_production.

[13] https://en.wikipedia.org/wiki/list_of_countries_by_percentage_of_population_livin

[14] http:www.transparency.org/news/feature/Nigerians_corruption_challenge.

[15] Lyman. P. (2010). If Nigeria fails. The Nation January 7, p-14.

[16] Macridis, Roy. C. (1972). Foreign policy in world politics. Englewood Cliffs, New Jersey PrenticeHall International Inc.

[17] Morgenthau, H. J. (1978). Politics Among Nations, The Struggle for Power and Peace, New York (N.Y.): Alfred. A. Knopf, Inc.

[18] Nweke, A. G. (1985). Nigeria's national interest \& foreign policy. Nigerian Journal of International Affairs. 11(1). pp.1-32.

[19] Obiozor, G. ( 2010). Leadership, legitimacy and authority crisis in Nigerian politics (3). Daily Champion, July 21.

[20] Obiozor, G. (2010). Leadership, legitimacy and authority crisis in Nigerian politics (4). Daily Champion, July 22 . 
[21] Obiozor, G. (2010). Leadership, legitimacy and authority crisis in Nigerian politics (5). Daily Champion, July 23.

[22] Olusanya, G. \& Akindele R. A. (1986). Nigeria's foreign policy in the future: An introductory overview. Nigerian Journal of International Affairs, 12(1\&2) pp1-11.

[23] Osakwe, C. (2011). Nation building. In C. Ikokwu (Ed.), Nigeria: half a Century of progress and challenges (pp1-24), Nigeria: True Expression Press.

[24] Onu, G. (2000). Democratising the United Nations Security Council; implications for global peace. Nnamdi Azikiwe Journal of Political Science, 2(1) pp.12-20.

[25] Oyebode, O. (2010). Yar Adua's rule of Law mantra has failed critical test. The Nation, January 7, p-14.

[26] Rodney, W. (2009). How Europe underdeveloped Africa. Lagos: Panaf Publishing.

[27] Sunday Punch, May 30, 2010.

[28] Usman, T. (2015). Why Nigeria deserves a permanent UN Security Council Seat -Osinbajo. Premium Times, September 10. Retrieved from http://www.premiumtimesng.com/news/

[29] top-news/189771-why-Nigeria-deserves-a.

[30] Uhomoibhi, M. I. (2008). A triple web of interdependence: The UN, the Commonwealth and the EU, in Adekeye Adebajo \& Abdul. R. Mustapha (eds) Guliver's troubles Nigeria's foreign policy after the Cold War (pp223-254) Cape Town, South Africa: University of KwaZulu-Natal Press.

[31] Uhomoibhi, M. I. (2011). Nigeria's foreign policy; current features, enduring challenges and prospective solutions, in Constance Ikokwu (Ed.) Nigeria half a century of progress and challenges (pp102-114), Nigeria: True Expression Press. www.bbc.com/news/world_africa_17015873 of 13 th Feb.2012.

[32] www.index.mundi.com/g/r.aspx? $\mathrm{v}=69$ 